\title{
Is it time to adopt beating-heart coronary artery bypass grafting? A review of literature
}

\section{É hora de adotar a cirurgia de revascularização do miocárdio com o coração batendo? Revisão de literatura}

Emad Mohamed HIJAZI ${ }^{1}$

RBCCV 44205-1203

\section{Resumo}

Evitar a morbidade da circulação extracorpórea (CEC) deveria, teoricamente, reduzir a incidência de disfunção de órgãos e levar a melhora no estado dos pacientes. Recentemente, técnicas de estabilização mecânica cardíaca foram desenvolvidas, facilitando a cirurgia de revascularização do miocárdio com CEC. O uso da CEC pode influenciar o resultado econômico, mantendo a qualidade do atendimento e satisfação do paciente. As bases de dados MEDLINE, EMBASE, Cochrane Controlled Trials Register (CCTR), Banco de Dados Cochrane de Revisões Sistemáticas (CDSR), banco de dados de resumos de revisões dos Efeitos (DARE), Science Citation Index (SCI), Current Contents, NHS Database Avaliação Econômica e Rede Internacional de Agências de Avaliação de Tecnologias em Saúde (INAHTA) foram pesquisadas a partir da data da inserção até o final de março de 2008, utilizando os termos de busca circulação extracorpórea, cirurgia minimamente invasiva, coração batendo e suas variantes. A revascularização sem CEC oferece uma alternativa segura e econômica de revascularização miocárdica convencional com circulação extracorpórea (CRM) e parada cardioplégica.

Descritores: Circulação extracorpórea. Procedimentos cirúrgicos cardíacos. Ponte de artéria coronária. Revascularização miocárdica. Ponte de artéria coronária sem circulação extracorporeal.
1. MD. Assistant Professor of Cardiac Surgery - Consultant of Cardiac Surgery/Medical School - Jordan University of Science and Technology- Jordan/Irbid. Princess Muna AL-Hussein Cardiac Center, King Abdullah University Hospital. Department of General Surgery.

Trabalho realizado no King Abdullah University Hospital, Irbid, Jordan.

\begin{abstract}
Avoiding the morbidity of cardiopulmonary bypass should theoretically reduce the incidence of organ dysfunction and lead to improved patient outcomes. Recently, cardiac mechanical stabilization techniques were developed, facilitating on-pump CABG (OPCAB). The use of CPB may influence the economic outcome, while maintaining quality of care and patient satisfaction. MEDLINE, EMBASE, Cochrane Controlled Trials Register (CCTR), Cochrane Database of Systematic Reviews (CDSR), Database of Abstracts of Reviews of Effects (DARE), Science Citation Index (SCI), Current Contents, NHS Economic Evaluation Database (NEED), and International Network of Agencies for Health Technology Assessment (INAHTA) databases were searched from the date of their inception to the end of March 2008, using the search terms off-pump, minimally invasive, beating heart, coronary artery bypass, and their variants. Off-pump revascularization offers a safe, cost-effective alternative to conventional coronary revascularization with cardiopulmonary bypass (CABG) and cardioplegic arrest.
\end{abstract}

Descriptors: Extracorporeal circulation. Cardiac surgical procedures. Coronary artery bypass. Myocardial revascularization. Coronary artery bypass, off-pump.

Endereço para correspondência:

Emad M. Hijazi, MD PO Box 999 Irbid 22110 Jordan.

E-mail: emad_hijazi@hotmail.com 


\section{INTRODUCTION}

Coronary artery bypass grafting was first performed without the use of cardiopulmonary bypass (CPB) in the late 1960s [1], but this technique was largely abandoned after the use of $\mathrm{CPB}$ and cardioplegic arrest became routine [2]. CPB is known to induce inflammatory response that has been documented in the lungs, heart, central nervous system, kidneys, and gastrointestinal tract. Stroke is a well known complication related to CPB, cannulation, or surgical manipulation, cross-clamping of the ascending aorta. Interventional cardiologists have applied percutaneous myocardial revascularization to an increasing proportion of the population with coronary artery disease, leaving surgeons with an increasingly complex group of patients for surgical revascularization.

Cardiopulmonary bypass may be less well tolerated in these elderly patients who present with significant comorbidities [3]. Off-pump coronary bypass emerged as a new refined technique that is thought to provide a safer form of surgical revascularization by avoiding the unwanted complications of cardiopulmonary bypass, particularly in the increasingly complex patients being referred for operation [3]. Hemodynamic instability during OPCAB may prevent grafting of the posterior wall, thus compromising the basic principle of complete revascularization [4]. The Octopus as cardiac stabilization techniques is one of the devices that can immobilize andpresent all sides of the beating heart [5]. This allows off-pump coronary artery bypass grafting (CABG) in patients with 3-vessel disease [3]. Nevertheless, it has to be stated that the rate of incomplete revascularization in the early series of CABG without $\mathrm{CPB}$ is higher, and compromises the basic principle of complete revascularization [4]. There has been a lot concern regarding a decrement in graft patency rate in patients undergoing OPCAB.

The major determinant of costs in conventional coronary artery surgery still remain the variable and fixed direct costs in terms of materials used for routine operations, postoperative care, and the management of postoperative complications [6,7]. Therefore, further savings could be obtained by using a surgical technique able to decrease the fixed direct cost while maintaining clinical quality of care [8].

\section{METHODS}

MEDLINE, EMBASE, Cochrane Controlled Trials Register (CCTR), Cochrane Database of Systematic Reviews (CDSR), Database of Abstracts of Reviews of Effects (DARE), Science Citation Index (SCI), Current Contents, NHS Economic Evaluation Database (NEED), and International Network of Agencies for Health Technology
Assessment (INAHTA) databases were searched from the date of their inception to the end of March 2008, using the search terms off-pump, minimally invasive, beating heart, coronary artery bypass, and their variants. The study has been approved through The Jordanian University of Science and Technology Institutional Ethics Committee Jordan/ Irbid.

\section{DISCUSSION}

\section{Systemic Inflammatory Response (SIRS)}

SIRS has been documented in the lungs, heart, central nervous system, kidneys, and gastrointestinal tract. SIRS results from a cascade of events generated by the contact of plasma proteases and blood cells with the gaseous interface and bioincompatible surfaces of the CPB machine. Activation of plasma proteases generates pro-inflammatory mediators that activate leukocytes, vascular endothelial cells, and platelets. The resulting platelet degranulation, neutrophil and monocyte activation result in a cytokine release syndrome and, in extreme cases, the generation of a systemic inflammatory response $[9,10]$. Activated neutrophils, free oxygen radicals, and cytotoxins lead to myocardial edema and decreased contractility, thus directly contributing to cardiac dysfunction after CPB. The inflammatory response impairs pulmonary function through the degradation of surfactant and activation of complement and neutrophils, with resultant capillary permeability, interstitial edema, atelectasis, and decreased pulmonary compliance [11]. Several studies [12] have compared the inflammatory response in Off-pump vs. that in On-pump by the measurement of cytokines and acute phase proteins before and after surgery in serum. Thesehave demonstrated a significant attenuation of the inflammatory response with Off-pump. In principle, this reduction in systemic inflammation should be accompanied by a reduction in organ dysfunction.

\section{Blood loss and transfusion requirements}

Excessive bleeding is an important cause of morbidity and mortality after CPB. Bleeding after cardiac surgery has several causes [13]. The exposure of blood to synthetic, nonendothelial surfaces causes severe hemostatic defects that inhibit or alter many components of the thrombotic and fibrinolytic systems [14]. Because of the associated decrease in hemostatic function and the resultant blood loss, patients undergoing CPB are often given allogeneic blood transfusions [15].

Transfusion of allogeneic blood products exposes the patient to additional risks (transfusion reactions, viral transmission, immunosuppression, and increased mortality rates) and increases the cost of the procedure [14]. Morbidity and mortality rates and hospital costs increase 
substantially when re-exploration for bleeding is necessary [16]. Many recent studies documented the beneficiary effect of off-pump in reducing the rate of post operative bleeding and blood transfusion. In a prospective non-randomized cohort study, Casati et al. [13] demonstrated significantly higher antithrombin and plasminogen concentrations and reduced D-dimer formation (fibrinolysis) in patients undergoing off- compared to on-pump CABG. Randomized trials, matched cohort and retrospective studies [16-19] consistently demonstrate reduced blood loss, re-operation for bleeding and requirements for allogenic blood products in OPCAB than in on-pump patients. Ascione et al. [8], in their study shows that transfusion requirements were higher in the on-pump group, and this reflected the significantly higher mean transfusion costs, re-entry for bleeding occurred infrequently in the OPCAB group.

Puskas et al. [11], in a prospective randomized study, included 51 off-pump patients who were seen from November 1996 through December 1997 and underwent offpump CABG by a single surgeon at Crawford Long Hospital, Emory University. The control group included 245 patients, for a total sample of 296 patients. More than half of the patients in the control group required transfusion of one blood product or more during hospitalization, whereas less than a quarter of the off-pump group received any blood products. Puskas et al. [20] in retrospective study included 200 undergoing OPCAB by a single surgeon at Emory University. A statistically significant difference was found in favor of off pump group as compared to on pump group in regards of requirement of perioperative transfusion.

Cleveland et al. [21] using the Society of Thoracic Surgeons (STS) National Adult Cardiac Surgery Database, procedural outcomes were compared for conventional and off-pump CABG procedures from January 1, 1998, through December 31, 1999. A total of 126 experienced centers performed 118,140 total CABG procedures. The number of off-pump CABG cases was 11,717 cases (9.9\% of total cases). Importantly there data suggest that an off-pump strategy reduces the likelihood of reoperation for bleeding. There conclusion agrees with others [22,23] who have documented less perioperative bloodloss with off-pump CABG. The need for transfusion was significantly less in the beating heart group.

\section{Cerebral injury}

Permanent neurologic dysfunction (stroke or coma) after conventional CABG is a devastating complication. Cerebral injury is considered to be the most significant and disabling complication of CABG. Stroke occurs in roughly $3 \%$ of patients after CABG, although up to two thirds of patients show a cognitive decline of variable duration [24]. Although the pathogenesis of cerebral injury and cognitive dysfunction after cardiac surgery is multifactorial, there is increasing evidence that multiple microemboli arising from the ascending aorta, the heart chambers, or the bypass circuit are the primary pathophysiologic mechanisms producing diffuse ischemic cerebral injury [25]. Theoretically procedures that do not use CPB are likely to prevent these unwanted effects. In fact, cerebral microembolization is markedly reduced when CPB is avoided [26,27]. However, reducing cerebral microembolization by avoiding CPB has not resulted in a statistically significant reduction in the incidence of stroke and postoperative neurocognitive dysfunction [28].

The comparable incidence of postoperative stroke after OPCAB may be attributable to aortic manipulation related to the use of a side-biting clamp that is applied during the construction of the proximal anastomoses [29]. Available evidence from the randomized controlled trials does not unequivocally show that OPCAB is better than conventional CABG with respect to occurrence of stroke and postoperative neurocognitive dysfunction $[17,18,30]$. The adoption of the aortic "no touch" technique, which avoids intraoperative atheromatous embolization from the atherosclerotic aorta into the cerebral circulation, may improve neurologic outcomes after OPCAB [31].

Cleveland et al. [21] suggest that off-pump CABG may protect against cerebrovascular accidents (CVA).The observed-to-expected ratio from the multivariate analysis for off-pump CABG and stroke is 0.62. Furthermore, analyzing the subgroup with preoperative cerebrovascular disease (CVD) suggests that off-pump CABG reduces the rate of postoperative CVA compared to conventional CABG. Again, the absolute risk of stroke was reduced from $4.6 \%$ to $2.5 \%$, a difference of $2.1 \%$. Clearly, previous reports have identified preoperative CVD as a robust predictor of postoperative adverse neurological events [32], and interventions to reduce this risk are necessary.

Bowles et al. [33], in a series comparing the occurrence of microemboli in patients undergoing coronary revascularization with and without $\mathrm{CPB}$, have demonstrated a significant reduction in the cerebral embolic burden with the elimination of the extracorporeal bypass circuit. Although manipulation does account for some of the emboli during CABG, the vast majority (84\%) occurred while the patient was receiving $\mathrm{CPB}$ with no specific surgical manipulation identified. In contrast, the relatively sparse emboli count recorded during OPCAB was more often related to surgical manipulation, especially lifting the heart for distal anastomoses and placing and releasing the partial occlusion aortic clamp. The results are interesting, they have demonstrated a significant reduction in the number of microemboli detected by transcranial Doppler ultrasonography, as well as a trend toward a reduction in the stroke rate in patients undergoing OPCAB compared 
with CABG. The true clinical significance of this dramatic reduction in cerebral microemboli, however, remains to be determined.

\section{Gastrointestinal dysfunction}

Gastrointestinal dysfunction following cardiac surgery, occur in about $2.5 \%$ of patients but with a disproportionate mortality (about 33\%) [34]. CPB is associated with significant physiologic alterations in mucosal perfusion, epithelial permeability, edema formation, and blood flow regulation. Inhibition of C5a limits neutrophil-mediated impairment of ileal microvascular regulation after bypass, but does not improve extravascular mesenteric dysfunction after CPB [35].

Severe intestinal mucosal ischemia can occur during CPB even when the indices of global perfusion remain normal. Factors released during $\mathrm{CPB}$, such as vasopressin, catecholamines, and thromboxane $\mathrm{A}_{2}$ and $\mathrm{B}_{2}$, lead to redistribution of blood flow away from the mucosa because of regional vasoconstriction, and may contribute to mucosal ischemia [35]. Velissaris et al. [36] recruited low-risk patients for a randomized controlled trial (RCT) evaluating global oxygen flux and gastric mucosal oxygenation during CABG with and without CPB. Their findings suggested that despite superior global oxygen flux associated with beatingheart revascularization, gastric mucosal hypoxia occurred to similar extents in both groups with worsening trends for the OPCAB patients postoperatively. The splanchnic pathophysiology during beating-heart revascularization should be further explored.

A prospective, randomised study done by Raja et al. [37] was designed to define the role of cardiopulmonary bypass (CPB) and cardioplegic arrest in the pathogenesis of gastrointestinal complications following coronary artery surgery. This prospective, randomised study was designed to define the role of cardiopulmonary bypass (CPB) and cardioplegic arrest in the pathogenesis of gastrointestinal complications following coronary artery surgery. They concluded that cardiopulmonary bypass, inclusive of cardioplegic arrest, is the main independent predictor of post-operative gastrointestinal complications in patients undergoing coronary revascularization.

\section{Acute renal failure}

The etiology of renal dysfunction after cardiac surgery is multi-factorial [38] and in patients with co-morbid conditions that are associated with post-operative renal dysfunction (elderly, diabetics, renal impairment), CPB is associated with an increased risk of dialysis dependant renal failure [39,40]. However, renal hypoperfusion and inflammatory damage resulting from $\mathrm{CPB}$ are widely regarded as the most important causes of acute renal failure [41,42]. Beating Heart versus Cardioplegic Arrest Studies (BHACAS-1 study) [43], as well as a non-randomized prospective study [44], demonstrated a significant reduction in glomerular (creatinine clearance) and tubular function (fractional excretion of sodium and free water clearance) in on-pump compared to off-pump surgery [44]. In a prospective randomized trial, Ascione et al. [43] used biochemical evaluation to show that off-pump reduced the frequency of renal impairment. Loef et al. [44] recruited 22 low-risk patients ( 10 of whom underwent OPCAB and 12 , conventional CABG) to a randomized controlled trials (RCT) studying the progress and extent of renal damage after bypass surgery. The results showed that OPCAB induced significantly fewer changes in microalbuminuria $(P<0.01)$, free sodium clearance $(P<0.05)$, free water clearance $(P<0.01)$, $\mathrm{N}$-acetyl glucosaminidase activity $(P<0.01)$, and free hemoglobin $(P<0.01)$ than did bypass procedures using CPB.

In addition, the retrospective study by Magee et al. [45] demonstrated a reduction in the frequency of renal failure after Off-pump (2.1\% vs. 3.3\%, respectively), despite significantly worse preoperative renal function in this group. These findings were consistent with results from other retrospective studies.

\section{Myocardial injury}

During CPB, before and after cardioplegia or fibrillatory arrest, the heart, like all other organs and tissues, is subject to microemboli, protease and chemical cytotoxins, activated neutrophils and monocytes, and regional hypoperfusion [46]. Both myocardial edema and distention of the flaccid cardioplegic heart during aortic cross-clamping reduce myocardial contractility [47]. Furthermore, if myocardial contractility is weak, excessive preloading or high after loading during weaning from $\mathrm{CPB}$ increases ventricular enddiastolic volume, myocardial wall stress, and oxygen consumption [46]. Off-pump should therefore reduce myocardial injury, since it allows continuous perfusion of the beating heart [48]. In the randomized trial conducted by Angelini et al. [17] the frequency of myocardial infarction was reduced in the off-pump group (2\%), relative to the onpump group (4\%), at 2 years of follow-up. More recently, cardiovascular MRI has provided evidence in support of reduced myocardial injury with off-pump [48].

Several randomized controlled trials (RCTs) [28] have found that the incidence of postoperative myocardial infarction is comparable after OPCAB and CABG with CPB but that OPCAB is associated with a more rapid recovery of myocardial oxidative metabolism, better myocardial function, and a lower requirement for inotropic agents. Puskas et al. [11] in a prospective randomized study reported no incidence of myocardial infarction with significant reduction in postoperative intraaortic balloon pump use in the off-pump group and a strong trend toward a reduction in requirement of inotropic support. In a randomized trial of 60 patients, Selvanayagam et al. [49] 
reported significantly better postoperative left ventricular function in the Off-pump group. Vedin et al. [50] have found that immediately after surgery (OPCAB), there was better cardiovascular performance and less release of markers of myocardial damage after OPCAB. Sahlman et al. [51] reported less CK-MB release and better myocardial preservation in OPCAB patients.

\section{Atrial fibrillation}

Atrial fibrillation (AF), the most common complication of CABG, occurs in $20 \%$ to $40 \%$ of patients [52]. By avoiding the atrial myocyte alterations that result from aortic crossclamping and avoiding the systemic inflammatory response to $\mathrm{CPB}, \mathrm{OPCAB}$ should decrease the incidence of postoperative AF [28]. There is a general consensus from randomized trials $[18,53,54]$ and prospective nonrandomized cohort studies $[55,56]$ that CABG performed using $\mathrm{CPB}$ and cardioplegic arrest is associated with a significantly greater degree of myocardial injury than OPCAB. Puskas et al. [11] founds no difference in the incidence of atrial fibrillation between groups, despite the absence of atrial sutures, cannulation, and CPB in the offpump group. Both groups received a similar postoperative regimen of tapering beta-blockade as prophylaxis against atrial fibrillation.

A retrospective analysis of 72 patients undergoing myocardial revascularization was performed by Scherer et al. [57], concluded that avoiding cardiopulmonary bypass and minimizing surgical trauma did not reduce the incidence of postoperative AF in this patient collective. It remains an attractive hypothesis that postoperative AF is reduced by off-pump myocardial revascularization and minimizing surgical trauma but more robust data are required. Two metaanalyses have been performed to evaluate the impact of OPCAB on the incidence of atrial fibrillation [58,59], and all found that the incidence of postoperative AF is substantially lower after OPCAB. Angelini et al. [17] performed a pooled analysis of the Beating Heart Against Cardioplegic Arrest Studies (BHACAS 1 and 2) and found that the incidence of AF decreased from $37 \%$ to $13 \%$ with OPCAB, which was a highly significant finding.

\section{Pulmonary dysfunction}

Pulmonary functions deteriorate significantly for at least 3.5 months after cardiac surgery. Preoperative cardiac ischaemic and failure symptoms are inversely related to perioperative pulmonary function tests (PFTs) [60]. Compared to $\mathrm{CABG}$ with $\mathrm{CPB}, \mathrm{OPCAB}$ was associated with a greater reduction in postoperative respiratory compliance associated with increased fluid administration and rotation of the heart into the right chest to perform posterolateral grafts. OPCAB yielded better gas exchange and earlier extubation but no difference in chest radiographs, spirometry, or rates of death, pneumonia, pleural effusion, or pulmonary edema [61].

Avoiding full heparinization allows safe use of a thoracic epidural catheter. Apart from thoracic sympatholysis, this may lead to improved postoperative pain relief and reduced mechanical ventilation time [62]. Most randomized controlled trials (RCTs) that have recruited low-risk patients have shown that OPCAB definitely reduces the duration of ventilation and allows earlier extubation of OPCAB patients, yet its effects on respiratory mechanics, oxygenation, and effort of breathing are similar to those in patients undergoing CABG with CPB [28]. The benefits of $\mathrm{OPCAB}$ are more pronounced in patients with preexisting pulmonary disease. In these patients, adverse effects on the alveolar stability by activation of the complement cascade, sequestration of the neutrophil in the pulmonary microvascular bed, release of oxygen-derived free radicals, and changes in the composition of alveolar surfactant are not seen, because CPB is avoided [63,64].

Length of hospital stay, mortality rates and cost savings

The length of hospital stay and the incidence of death after CABG is a function of multiple variables primarily related to a patients premorbid condition and the morbidity associated with the procedure [28]. Three large metaanalyses $[59,65,66]$ have reported that the mortality rate after OPCAB is comparable with that seen after CABG and $\mathrm{CPB}$ but that the duration of hospital stay is substantially reduced in patients who undergo OPCAB. Two of these meta-analyses $[65,66]$ pooled the results of randomized controlled trial (RCTs) only. Similar results were later found by several RCTs $[30,67]$. By reducing the morbidity rates associated with the procedure and decreasing the incidence of complications, the use of OPCAB has decreased the length of hospital stay [28]. Cleveland et al. [21] showed that the risk-adjusted mortality in the conventional CABG group was $2.93 \%$, where as the mortality in the off-pump CABG group was $2.31 \%$, which was significantly lower $(P<$ $0.0001)$. The absolute reductionin mortality was $0.61 \%$.

Hart et al. [3] review the entire experience of the Medtronic Octopus System (Medtronic, Minneapolis, MN) for beating heart bypass from 7 surgeons. A total of 1,582 patients underwent attempted Octopus OPCAB. Inhospital or 30 -day mortality was also low at $1.0 \%$ (range $0 \%$ to $3.7 \%$ ). Postoperative length of stay averaged 5.8 days (range 4.9 to 7.6 days). The gratifyingly low rates of morbidity and mortality demonstrated in this large group of OPCAB patients compare favorably with the early outcomes described in recent reports of CPB-supported CABG [68]. Three RCTs have compared the economic outcomes of Off-pump with those of On-pump $[8,67,68]$, and founds that OPCAB is less expensive than conventional CABG because of lower complication rates, shorter 
intubation times and shorter stays in the ICU and hospital for Off-pump patients.

\section{Graft patency and quality of anastomosis}

Many authors [2,69] have reported series of OPCAB. Although they have presented excellent mortality rates, concern has been rased over a decrement in graft patency rates [70]. One of the main concerns about OPCAB is that performing vascular anastomoses on the small arteries of a beating heart compromises graft patency and results in incomplete myocardial revascularization [71]. The two larger randomized controlled trials (RCTS) [67,72] showed no significant differences in patency at various time points. More recently, however, the results of BHACAS trials 1 and 2 showed no difference (at a mean follow-up of 29 months and 16 months, respectively) between OPCAB and CABG with bypass groups in terms of late mortality, cardiac events, and the need for further coronary revascularization procedures [17]. This evidence is supported by angiographic studies of Off-pump procedures, which have demonstrated graft patency rates at least equivalent to those of On-pump procedures [23]. Khan et al. [73] reported patency rates of $88 \%$ and $98 \%$, respectively, in OPCAB and CABG with bypass surgery. However, a closer analysis of this study [73] shows that the limited experience of the surgeons, coupled with the intraoperative administration of a relatively low dose of heparin, the absence of aggressive postoperative antiplatelet therapy with clopidogrel, and the failure to use new suction devices to optimize exposure, may have confounded the analyses of graft patency among patients who underwent off-pump procedures [74].

Kim et al. [75] done a study including 402 patients who underwent off-pump coronary artery bypass surgery. Morphologic changes of grafts were traced by the Fitz Gibbon grading system. They proved that midterm angiographic follow-up demonstrated acceptable patency rates of grafts after off-pump coronary artery bypass surgery. Approximately half of the Fitz Gibbon grade B arterial grafts in the early angiograms became grade $\mathrm{A}$ at 5 years after surgery, but the proportion of grade B saphenous vein grafts gradually increased over the 5 postoperative years. Muneretto et al. [76] prospectively enrolled 176 patients undergoing total arterial myocardial revascularization and assigned them at random to one of two groups: group 1 was composed of 88 patients undergoing coronary surgery with cardiopulmonary bypass (CPB); group 2 consisted of 88 patients receiving the OPCAB procedure. They concluded that Off-pump coronary artery surgery could be successfully used for total arterial grafting without compromising the completeness of revascularization.

El-Hamamsy et al. [77] in there series, showed that complete coronary revascularization was accomplished in
95\% of cases (average 3.2 grafts/patient). Although completeness of revascularization was a major concern in the early era of beating heart surgery, most recent series have shown the absence of any such disparity between OPCAB and conventional on-pump CABG [18]. However, with the advent of newer stabilizers and low-profile apical suction devices, this problem has been all but solved [18]. All the vessels of the heart are now approached with the improvement of biomedical technology and suction stabilizer. The compression device (Speroni) is more associated with changes than the suction device (Octopus) [78]. Milani et al. [79], in a prospective study, suggested that the operation for myocardial revascularization is safe and efficient and can be applied to all patients who need coronary surgery, with low rates of complication and mortality. In a prospective study Pinto e Silva et al. [80] showed that the in-hospital outcome of elderly patients aged 70 years and older who underwent off-pump coronary artery bypass graft surgery with an intraluminal shunt in urgent, emergent, and elective coronary revascularizations associated with low rates of postoperative complications and mortality in relation to the studied population. They concluded that in same group patients (over 70 years-old), elective and non-elective off-pump coronary artery bypass grafting with intracoronary shunt showed to be safe and effective.

\section{Future developments}

Introduction of recent improved mechanical stabilizing devices facilitated multivessel OPCAB. Eliminating the need for aortic manipulation and CPB, aortic "no touch" technique and total arterial grafting offering the advantages of longevity of arterial grafts in a younger population, avoids intraoperative atheromatous embolization from the atherosclerotic aorta into the cerebral circulation, and reduce the risk of neurological complications in the elderly after OPCAB. Improving of sutureless anastomotic devices eliminates the need for side-biting aortic clamps avoiding dislodgment of atheromatous material and improving the neurologic outcome. The further development of distal coronary anastomotic devices may technical improving the distal coronary anastomoses especially with OPCAB surgery. The reproducibility and the feasibility of teaching the new surgical technique will reflect on its widespread adoption among the next generation of surgeons. Stepwise introduction of OPCAB can lead to improved overall total coronary artery revascularization surgical outcomes.

\section{CONCLUSION}

Off-pump coronary artery bypass grafting is safe, reduces hospital cost, postoperative length of stay, decreased mortality and morbidity compared with CABG on cardiopulmonary bypass. OPCAB surgery associated 
with excellent graft patency, significantly fewer cerebral microemboli. The present review demonstrates the safety and efficacy of OPCAB surgery in nonselected patients on long-term outcomes. Therefore, with increasing follow-up periods, OPCAB surgery remains a viable and widely applicable surgical option for patients with coronary insufficiency.

\section{REFERENCES}

1. Kirklin JK, Westaby S, Blackstone EH, Kirklin JW, Chenoweth DE, Pacifico AD. Complement and the damaging effects of cardiopulmonary bypass. J Thorac Cardiovasc Surg. 1983;86(6):845-57.

2. Buffolo E, Andrade CS, Branco JN, Teles CA, Aguiar LF, Gomes WJ. Coronary arteries bypass grafting without cardiopulmonary bypass. Ann Thorac Surg. 1996;61(1):63-6.

3. Hart JC, Spooner TH, Pym J, Flavin TF, Edgerton JR, Mack MJ, et al. A review of 1,582 consecutive Octopus off-pump coronary bypass patients. Ann Thorac Surg. 2000;70(3):1017-20.

4. Czerny M, Baumer H, Kilo J, Zuckermann A, Grubhofer G, Chevtchik O, et al. Complete revascularizations in coronary artery bypass grafting with and without cardiopulmonary bypass. Ann Thorac Surg. 2001;71(1):165-9.

5. Borst C, Jansen EW, Tulleken CA, Gründeman PF, Mansvelt Beck HJ, van Dongen JW, et al. Coronary artery bypass grafting without cardiopulmonary bypass and without interruption of native coronary flow using a novel anastomosis site restraining device ("Octopus"). J Am Coll Cardiol. 1996;27(6):1356-64.

6. Smith PK, Smith LR, Muhlbaier LH. Risk stratification for adverse economic outcomes in cardiac surgery. Ann Thorac Surg. 1997;64(6 Suppl):S61-3.

7. Williams TE Jr, Fanning WJ, Link L, Benton WC, Kakos GS, Miller RL, et al. Can we afford to do cardiac operations in 1996? A risk-reward curve for cardiac surgery. Ann Thorac Surg. 1994;58(3):815-20.

8. Ascione R, Lloyd CT, Underwood MJ, Lotto AA, Pitsis AA, Angelini GD. Economic outcome of off-pump coronary artery bypass surgery: a prospective randomized study. Ann Thorac Surg. 1999;68(6):2237-42.

9. Mojcik CF, Levy JH. Aprotinin and the systemic inflammatory response after cardiopulmonary bypass. Ann Thorac Surg. 2001;71(2):745-54.

10. Paparella D, Yau TM, Young E. Cardiopulmonary bypass induced inflammation: pathophysiology and treatment. An update. Eur J Cardiothorac Surg. 2002;21(2):232-44.
11. Puskas JD, Wright CE, Ronson RS, Brown WM 3rd, Gott JP, Guyton RA. Off-pump multivessel coronary bypass via sternotomy is safe and effective. Ann Thorac Surg. 1998;66(3):1068-72.

12. Diegeler A, Doll N, Rauch T, Haberer D, Walther T, Falk V, et al. Humoral immune response during coronary artery bypass grafting: a comparison of limited approach, "off-pump" technique, and conventional cardiopulmonary bypass. Circulation. 2000;102(19 Suppl 3):III95-100.

13. Casati V, Gerli C, Franco A, Della Valle P, Benussi S, Alfieri O, et al. Activation of coagulation and fibrinolysis during coronary surgery: on-pump versus off-pump techniques. Anesthesiology. 2001;95(5):1103-9.

14. Ereth MH, Nuttall GA, Oliver WC Jr, Santrach PJ, Price RD, Schaff HV. Temperature and duration of cardiopulmonary bypass influence transfusion requirements. J Clin Anesth. 1998;10(7):588-92.

15. Stensrud PE, Nuttall GA, de Castro MA, Abel MD, Ereth $\mathrm{MH}$, Oliver WC Jr, et al. A prospective, randomized study of cardiopulmonary bypass temperature and blood transfusion. Ann Thorac Surg. 1999;67(3):711-5.

16. Lytle BW, Loop FD, Cosgrove DM, Taylor PC, Goormastic M, Peper W, et al. Fifteen hundred coronary reoperations. Results and determinants of early and late survival. J Thorac Cardiovasc Surg. 1987;93(6):847-59.

17. Angelini GD, Taylor FC, Reeves BC, Ascione R. Early and midterm outcome after off-pump and on-pump surgery in Beating Heart Against Cardioplegic Arrest Studies (BHACAS 1 and 2): a pooled analysis of two randomised controlled trials. Lancet. 2002;359(9613):1194-9.

18. Puskas JD, Williams WH, Duke PG, Staples JR, Glas KE, Marshall JJ, et al. Off-pump coronary artery bypass grafting provides complete revascularization with reduced myocardial injury, transfusion requirements, and length of stay: a prospective randomized comparison of two hundred unselected patients undergoing off-pump versus conventional coronary artery bypass grafting. J Thorac Cardiovasc Surg. 2003;125(4):797-808.

19. Kshettry VR, Flavin TF, Emery RW, Nicoloff DM, Arom KV, Petersen RJ. Does multivessel, off-pump coronary artery bypass reduce postoperative morbidity? Ann Thorac Surg. 2000;69(6):1725-30.

20. Puskas JD, Thourani VH, Marshall JJ, Dempsey SJ, Steiner MA, Sammons BH, et al. Clinical outcomes, angiographic patency, and resource utilization in 200 consecutive off-pump coronary bypass patients. Ann Thorac Surg. 2001;71(5):1477-83.

21. Cleveland JC Jr, Shroyer AL, Chen AY, Peterson E, Grover FL. Off-pump coronary artery bypass grafting decreases risk- 
adjusted mortality and morbidity. Ann Thorac Surg. 2001;72(4):1282-8.

22. Cartier R, Brann S, Dagenais F, Martineau R, Couturier A. Systematic off-pump coronary artery revascularization in multivessel disease: experience of three hundred cases. J Thorac Cardiovasc Surg. 2000;119(2):221-9.

23. Arom KV, Flavin TF, Emery RW, Kshettry VR, Janey PA, Petersen RJ. Safety and efficacy of off-pump coronary artery bypass grafting. Ann Thorac Surg. 2000;69(3):704-10.

24. Taggart DP, Westaby S. Neurological and cognitive disorders after coronary artery bypass grafting. Curr Opin Cardiol. 2001;16(5):271-6.

25. Knipp SC, Matatko N, Wilhelm H, Schlamann M, Massoudy $\mathrm{P}$, Forsting $\mathrm{M}$, et al. Evaluation of brain injury after coronary artery bypass grafting. A prospective study using neuropsychological assessment and diffusion-weighted magnetic resonance imaging. Eur J Cardiothorac Surg. 2004;25(5):791-800.

26. Lund C, Hol PK, Lundblad R, Fosse E, Sundet K, Tennøe B, et al. Comparison of cerebral embolization during off-pump and on-pump coronary artery bypass surgery. Ann Thorac Surg. 2003;76(3):765-70.

27. Bowles BJ, Lee JD, Dang CR, Taoka SN, Johnson EW, Lau $\mathrm{EM}$, et al. Coronary artery bypass performed without the use of cardiopulmonary bypass is associated with reduced cerebral microemboli and improved clinical results. Chest. 2001;119(1):25-30.

28. Raja SG. Pump or no pump for coronary artery bypass. Current best available evidence. Tex Heart Inst J. 2005;32(4):489-501.

29. Kapetanakis EI, Stamou SC, Dullum MK, Hill PC, Haile E, Boyce SW, et al. The impact of aortic manipulation on neurologic outcomes after coronary artery bypass surgery: a risk-adjusted study. Ann Thorac Surg. 2004;78(5):1564-71.

30. Légaré JF, Buth KJ, King S, Wood J, Sullivan JA, Hancock Friesen $\mathrm{C}$, et al. Coronary bypass surgery performed off pump does not result in lower in-hospital morbidity than coronary artery bypass grafting performed on pump. Circulation. 2004;109(7):887-92.

31. Leacche M, Carrier M, Bouchard D, Pellerin M, Perrault LP, Pagá $\mathrm{P}$, et al. Improving neurologic outcome in off-pump surgery: the "no touch" technique. Heart Surg Forum. 2003;6(3):169-75.

32. Almassi GH, Sommers T, Moritz TE, Shroyer AL, London MJ, Henderson WG, et al. Stroke in cardiac surgical patients: determinants and outcome. Ann Thorac Surg. 1999;68(2):391-7.

33. Bowles BJ, Lee JD, Dang CR, Taoka SN, Johnson EW, Lau EM, et al. Coronary artery bypass performed without the use of cardiopulmonary bypass is associated with reduced cerebral microemboli and improved clinical results. Chest. 2001;119(1):25-30.

34. Hessel EA 2nd. Abdominal organ injury after cardiac surgery. Semin Cardiothorac Vasc Anesth. 2004;8(3):243-63.

35. Tofukuji M, Stahl GL, Metais C, Tomita M, Agah A, Bianchi C, et al. Mesenteric dysfunction after cardiopulmonary bypass: role of complement C5a. Ann Thorac Surg. 2000;69(3):799-807.

36. Velissaris T, Tang A, Murray M, El-Minshawy A, Hett D, Ohri S. A prospective randomized study to evaluate splanchnic hypoxia during beating-heart and conventional coronary revascularization. Eur J Cardiothorac Surg. 2003;23(6):917-24.

37. Raja SG, Haider Z, Ahmad M. Predictors of gastrointestinal complications after conventional and beating heart coronary surgery. Surgeon. 2003;1(4):221-8.

38. Conlon PJ, Stafford-Smith M, White WD, Newman MF, King S, Winn MP, et al. Acute renal failure following cardiac surgery. Nephrol Dial Transplant. 1999;14(5):1158-62.

39. Ascione R, Nason G, Al-Ruzzeh S, Ko C, Ciulli F, Angelini GD. Coronary revascularization with or without cardiopulmonary bypass in patients with preoperative nondialysis-dependent renal insufficiency. Ann Thorac Surg. 2001;72(6):2020-5.

40. Yokoyama T, Baumgartner FJ, Gheissari A, Capouya ER, Panagiotides GP, Declusin RJ. Off-pump versus on-pump coronary bypass in high-risk subgroups. Ann Thorac Surg. 2000;70(5):1546-50.

41. Leurs PB, Mulder AW, Fiers HA, Hoorntje SJ. Acute renal failure after cardiovascular surgery. Current concepts in pathophysiology, prevention and treatment. Eur Heart J. 1989;10(Suppl H):38-42.

42. Hashimoto K, Miyamoto H, Suzuki K, Horikoshi S, Matsui $\mathrm{M}$, Arai $\mathrm{T}$, et al. Evidence of organ damage after cardiopulmonary bypass. The role of elastase and vasoactive mediators. J Thorac Cardiovasc Surg. 1992;104(3):666-73.

43. Ascione R, Lloyd CT, Underwood MJ, Gomes WJ, Angelini GD. On-pump versus off-pump coronary revascularization: evaluation of renal function. Ann Thorac Surg. 1999;68(2):493-8.

44. Loef BG, Epema AH, Navis G, Ebels T, van Oeveren W, Henning RH. Off-pump coronary revascularization attenuates transient renal damage compared with on-pump coronary revascularization. Chest. 2002;121(4):1190-4.

45. Magee MJ, Jablonski KA, Stamou SC, Pfister AJ, Dewey TM, Dullum MK, et al. Elimination of cardiopulmonary bypass improves early survival for multivessel coronary artery bypass patients. Ann Thorac Surg. 2002;73(4):1196-202. 
46. Hammon JW Jr, Edmunds LH Jr. Extracorporeal circulation: organ damage. In: Cohn LH, Edmunds LH Jr, editors. Cardiac surgery in the adult. 2nd ed. New York: McGraw-Hill;2003. p.361-88.

47. Downing SW, Savage EB, Streicher JS, Bogen DK, Tyson GS, Edmunds LH Jr. The stretched ventricle. Myocardial creep and contractile dysfunction after acute nonischemic ventricular distention. J Thorac Cardiovasc Surg. 1992;104(4):996-1005.

48. Keenan TD, Abu-Omar Y, Taggart DP. Bypassing the pump: changing practices in coronary artery surgery. Chest. 2005;128(1):363-9.

49. Selvanayagam JB, Petersen SE, Francis JM, Robson MD, Kardos A, Neubauer S, et al. Effects of off-pump versus onpump coronary surgery on reversible and irreversible myocardial injury: a randomized trial using cardiovascular magnetic resonance imaging and biochemical markers. Circulation. 2004;109(3):345-50.

50. Vedin J, Jensen U, Ericsson A, Bitkover C, Samuelsson S, Bredin F, et al. Cardiovascular function during the first 24 hours after off pump coronary artery bypass grafting: a prospective, randomized study. Interact Cardiovasc Thorac Surg. 2003;2(4):489-94.

51. Sahlman A, Ahonen J, Nemlander A, Salmenperä M, Eriksson $\mathrm{H}$, Rämö J, et al. Myocardial metabolism on off-pump surgery: a randomized study of 50 cases. Scand Cardiovasc J. 2003;37(4):211-5.

52. Zangrillo A, Landoni G, Sparicio D, Benussi S, Aletti G, Pappalardo F, et al. Predictors of atrial fibrillation after offpump coronary artery bypass graft surgery. J Cardiothorac Vasc Anesth. 2004;18(6):704-8.

53. Ascione R, Lloyd CT, Gomes WJ, Caputo M, Bryan AJ, Angelini GD. Beating versus arrested heart revascularization: evaluation of myocardial function in a prospective randomized study. Eur J Cardiothorac Surg. 1999;15(5):685-90.

54. Penttilä HJ, Lepojärvi MV, Kiviluoma KT, Kaukoranta PK, Hassinen IE, Peuhkurinen KJ. Myocardial preservation during coronary surgery with and without cardiopulmonary bypass. Ann Thorac Surg. 2001;71(2):565-71.

55. Louagie Y, Jamart J, Broka S, Collard E, Scavée V, Gonzalez M. Off-pump coronary artery bypass grafting: a case-matched comparison of hemodynamic outcome. Eur J Cardiothorac Surg. 2002;22(4):552-8.

56. Piacenza AE, Cacheda JH, Badaracco JR, Benetti FJ. Troponin as a marker of myocardial damage during coronary surgery with and without cardiopulmonary bypass. J Cardiovasc Surg (Torino). 2001;42(6):709-12.

57. Scherer M, Sirat AS, Dogan S, Aybek T, Moritz A, WimmerGreinecker G. Does totally endoscopic access for off-pump cardiac surgery influence the incidence of postoperative atrial fibrillation in coronary artery bypass grafting? A preliminary report. Cardiovasc Eng. 2006;6(3):118-21.

58. Athanasiou T, Aziz O, Mangoush O, Weerasinghe A, Al-Ruzzeh $\mathrm{S}$, Purkayastha $\mathrm{S}$, et al. Do off-pump techniques reduce the incidence of postoperative atrial fibrillation in elderly patients undergoing coronary artery bypass grafting? Ann Thorac Surg. 2004;77(5):1567-74.

59. Reston JT, Tregear SJ, Turkelson CM. Meta-analysis of shortterm and mid-term outcomes following off-pump coronary artery bypass grafting. Ann Thorac Surg. 2003;76(5):1510-5.

60. Shenkman Z, Shir Y, Weiss YG, Bleiberg B, Gross D. The effects of cardiac surgery on early and late pulmonary functions. Acta Anaesthesiol Scand. 1997;41(9):1193-9.

61. Staton GW, Williams WH, Mahoney EM, Hu J, Chu H, Duke PG, et al. Pulmonary outcomes of off-pump vs. on-pump coronary artery bypass surgery in a randomized trial. Chest. 2005;127(3):892-901.

62. Nierich AP, Diephuis J, Jansen EW, van Dijk D, Lahpor JR, Borst C, et al. Embracing the heart: perioperative management of patients undergoing off-pump coronary artery bypass grafting using the octopus tissue stabilizer. J Cardiothorac Vasc Anesth. 1999;13(2):123-9.

63. Covino E, Santise G, Di Lello F, De Amicis V, Bonifazi R, Bellino I, et al. Surgical myocardial revascularization (CABG) in patients with pulmonary disease: beating heart versus cardiopulmonary bypass. J Cardiovasc Surg (Torino). 2001;42(1):23-6.

64. Güler M, Kirali K, Toker ME, Bozbuga N, Omeroglu SN, Akinci E, et al. Different CABG methods in patients with chronic obstructive pulmonary disease. Ann Thorac Surg. 2001;71(1):152-7.

65. Parolari A, Alamanni F, Cannata A, Naliato M, Bonati L, Rubini $\mathrm{P}$, et al. Off-pump versus on-pump coronary artery bypass: meta-analysis of currently available randomized trials. Ann Thorac Surg. 2003;76(1):37-40.

66. van der Heijden GJ, Nathoe HM, Jansen EW, Grobbee DE. Meta-analysis on the effect of off-pump coronary bypass surgery. Eur J Cardiothorac Surg. 2004;26(1):81-4.

67. Puskas JD, Williams WH, Mahoney EM, Huber PR, Block PC, Duke PG, et al. Off-pump vs. conventional coronary artery bypass grafting: early and 1-year graft patency, cost, and quality-of-life outcomes: a randomized trial. JAMA. 2004;291(15):1841-9.

68. Sundt TM 3rd, Barner HB, Camillo CJ, Gay WA Jr. Total arterial revascularization with an internal thoracic artery and radial T graft. Ann Thorac Surg. 1999;68(2):399-404. 
69. Calafiore AM, Angelini GD, Bergsland J, Salerno TA. Minimally invasive coronary artery bypass grafting. Ann Thorac Surg. 1996;62(5):1545-8.

70. Subramanian VA, McCabe JC, Geller CM. Minimally invasive direct coronary artery bypass grafting: two-year clinical experience. Ann Thorac Surg. 1997;64(6):1648-53.

71. Raja SG. Safety of off-pump coronary artery surgery: no more skepticism please! Eur J Cardiothorac Surg. 2004;26(6):1229.

72. Nathoe HM, van Dijk D, Jansen EW, Suyker WJ, Diephuis JC, van Boven WJ, et al; Octopus Study Group. A comparison of on-pump and off-pump coronary bypass surgery in lowrisk patients. N Engl J Med. 2003;348(5):394-402.

73. Khan NE, De Souza A, Mister R, Flather M, Clague J, Davies $\mathrm{S}$, et al. A randomized comparison of off-pump and on-pump multivessel coronary-artery bypass surgery. N Engl J Med. 2004;350(1):21-8.

74. deGuzman BJ, Subramaniam MH. Off-pump versus onpump coronary bypass surgery. N Engl J Med. 2004;350(17):1791-3.

75. Kim KB, Cho KR, Jeong DS. Midterm angiographic followup after off-pump coronary artery bypass: serial comparison using early, 1-year, and 5-year postoperative angiograms. J Thorac Cardiovasc Surg. 2008;135(2):300-7.

76. Muneretto C, Bisleri G, Negri A, Manfredi J, Metra M, Nodari $\mathrm{S}$, et al. Off-pump coronary artery bypass surgery technique for total arterial myocardial revascularization: a prospective randomized study. Ann Thorac Surg. 2003;76(3):778-82.

77. El-Hamamsy I, Cartier R, Demers P, Bouchard D, Pellerin M. Long-term results after systematic off-pump coronary artery bypass graft surgery in 1000 consecutive patients. Circulation. 2006;114(1 Suppl):I486-91.

78. Oliveira PP, Braile DM, Vieira RW, Petrucci Junior O, Silveira Filho LM, Vilarinho KA, et al. Hemodynamic disorders related to beating heart surgery using cardiac stabilizers: experimental study. Rev Bras Cir Cardiovasc. 2007;22(4):407-15.

79. Milani R, Brofman P, Varela A, Moutinho JA, Guimarães M, Pantarolli R, et al. Total myocardium revascularization without extracorporeal circulation: five-year experience. Rev Bras Cir Cardiovasc. 2005;20(1):52-7.

80. Pinto e Silva AM, Campagnucci VP, Pereira WL, Rosa RF, Franken RA, Gandra SM, et al. Off-pump myocardial revascularization in the elderly: analysis of morbidity and mortality. Rev Bras Cir Cardiovasc. 2008;23(1):40-5. 